\title{
Optimization of the factors affecting the drying rate of cassava grates in a rotary drum dryer
}

\section{Daniel Leslie S. Tan', Gener G. Sebial² and Felix J. Amestoso ${ }^{3}$}

'Philippine Root Crops Research and Training Center, Visayas State University (formerly Leyte State University), Baybay City, Leyte, 6521-A, Philippines;

${ }^{2}$ Department of Agricultural Engineering, College of Engineering and Agro-Industries, Visayas State University, Baybay City, Leyte, 6521-A, Philippines;

${ }^{3}$ Department of Food Science and Technology, Visayas State University,

Baybay City, Leyte, 6521-A, Philippines

\begin{abstract}
This study determined the optimum effects of temperature, drum rotation and loading rate on the drying rate of cassava grates using the rotary drum dryer in removing moisture from cassava grates. A Central Composite Design was employed to evaluate a total of 15 fractional treatments derived from the 27 treatment combinations of temperature $\left(75,94\right.$ and $\left.113^{\circ} \mathrm{C}\right)$, drum rotation (15,20 and $\left.25 \mathrm{RPM}\right)$ and loading rate $(5,15$, and $25 \mathrm{~kg} /$ h). The response surface regression obtained optimum conditions of the factors and predicted values on the stationary point on water loss as well as the rate of water removal.

Results from the canonical analysis of response surface on plain water loss show an optimum combination of temperature of $107^{\circ} \mathrm{C}$, drum rotation of $23 \mathrm{RPM}$ and loading rate of $24 \mathrm{~kg} / \mathrm{h}$. At $25 \mathrm{~kg} / \mathrm{h}$ loading rate regardless of any variation of temperature and drum rotation, the rotation of the drum could not be sustained due to heavy load caused by the accumulated weight of the grates inside the drums. The optimum conditions and predicted response values for rate of plain moisture loss were observed to be: temperature of $108^{\circ} \mathrm{C}$, drum rotation of $23 \mathrm{RPM}$, loading rate of $26 \mathrm{~kg} / \mathrm{h}$. Response surface plots show the opposite effects between loading rates and temperature on the plain water loss as well as the rate of moisture loss. Response surface plots also revealed that RPM has no effect on the plain water loss and rate of moisture removal
\end{abstract}

Keywords: dried cassava grates, rotary drum dryer, response surface

Correspondence: D. L. S. Tan Address: Philippine Root Crops Training and Research Center (PhilRootcrops), Visayas State University, Baybay City, Leyte, 6521-A. Philippines. E-mail: dlstan@yahoo.com.Tel. No. (053) 335-2616

DOI: $10.32945 /$ atr2928.2007 


\section{INTRODUCTION}

Cassava (Manihot esculenta Crantz) is a starchy root crop grown almost entirely within the tropics. It is a very efficient producer of carbohydrates, and it grows even where the soil is poor and rainfall is uncertain (Cock and Weber, 1978). However, its rapid post-harvest deterioration limits its shelf-life and restricts the storage potential of the fresh roots to only a few days. This deterioration causes direct physical loss of the crop leading to low market value as a cash crop and consequently economic loss by the producers. To avoid such losses, processing the fresh cassava roots into dried chips and grates offer a potential solution tothe problem (Tan et al., 2000). Converting fresh cassava into dried chips and grates would maintain the quality of the products for a longer period.

Fresh cassava grates are processed into many different food products in the Philippines, which include cassava cake, suman, pitsi-pitsi, among many others (Troung, 1987). However, fresh cassava grates has a very short storage life that limits its transport and wide utilization. With this problem, dried cassava grates, which has a much longer shelf life than fresh grates, can be used as ingredients to substitute fresh cassava grates. Processing large amount of cassava grates, however, need equipment to facilitate the process. The Philippines Department of Agriculture-Bureau of Agricultural Research(DABAR) has funded a project for the improvement of the grates processing system (Tan, et al., 2004). This system includes the equipment for drying the grates such as the rotary drum dryer for grates. This dryer was found to perform the drying operation, but still needs further improvement because, as cited by Tan and Codilla (2003), cassava grates could be dried to $12 \%$ moisture content, wet basis, in less than 15 minutes in thin-layer drying at $70^{\circ} \mathrm{C}$ and $0.84 \mathrm{~m} / \mathrm{s}$ airflow conditions. This has not been attained by the rotary dryer except in its intial few minutes of operation. The grates need to pass through the dryer three times to get the desired moisture content of $12 \%$ or less.

The improvement of the dryer also means that drying operation would not be dependent upon the weather, but can operate anytime regardless of weather conditions, which also produces better quality product than that of sun drying. The continuous operation of the improved dryer also means continuous production of cassava grates and continuous supply of the grates to the market, which consequently would result to a continuous economic activity 

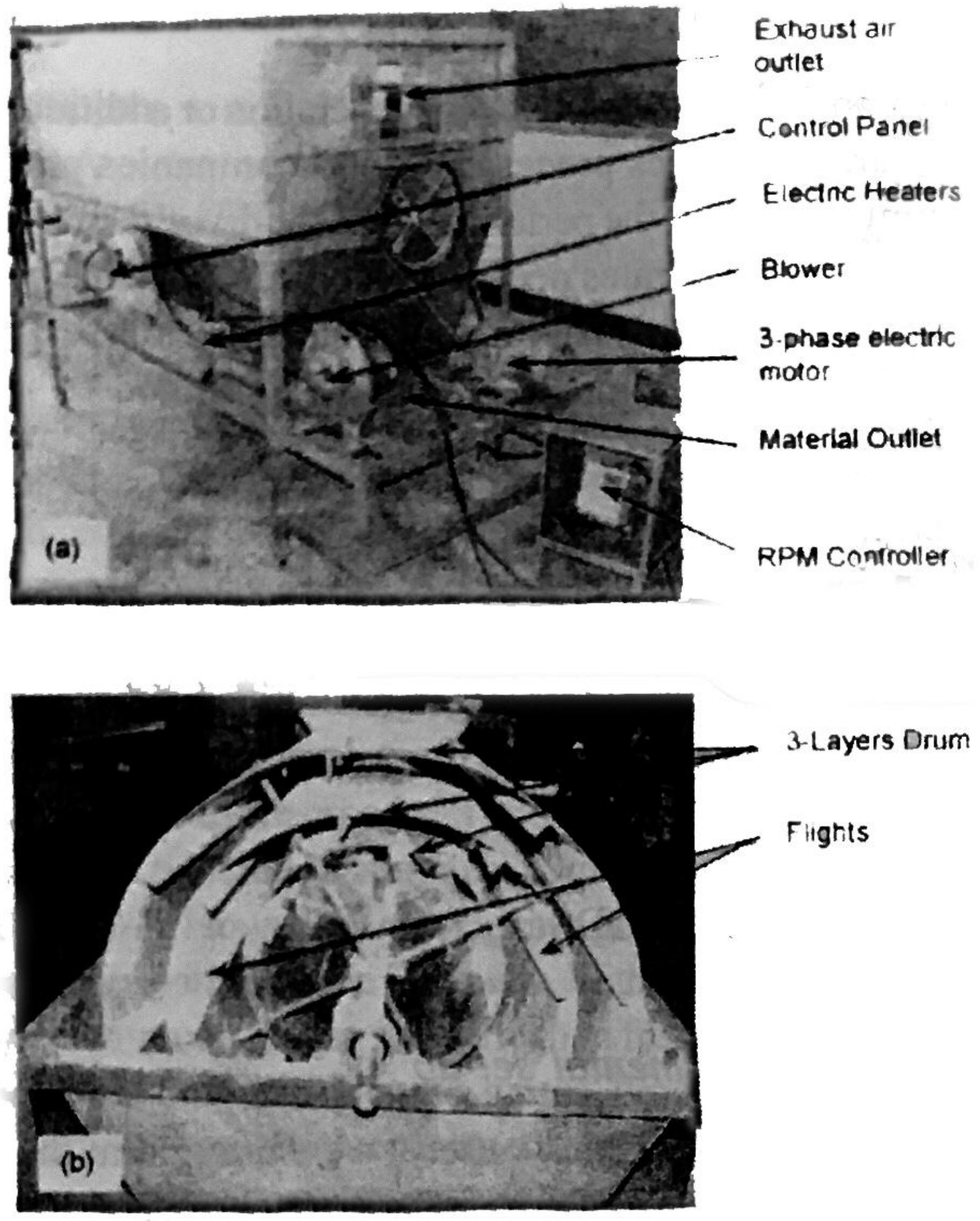

Figure 1. The IFS Modified Rotary Drum Dryer showing its perspective interior views

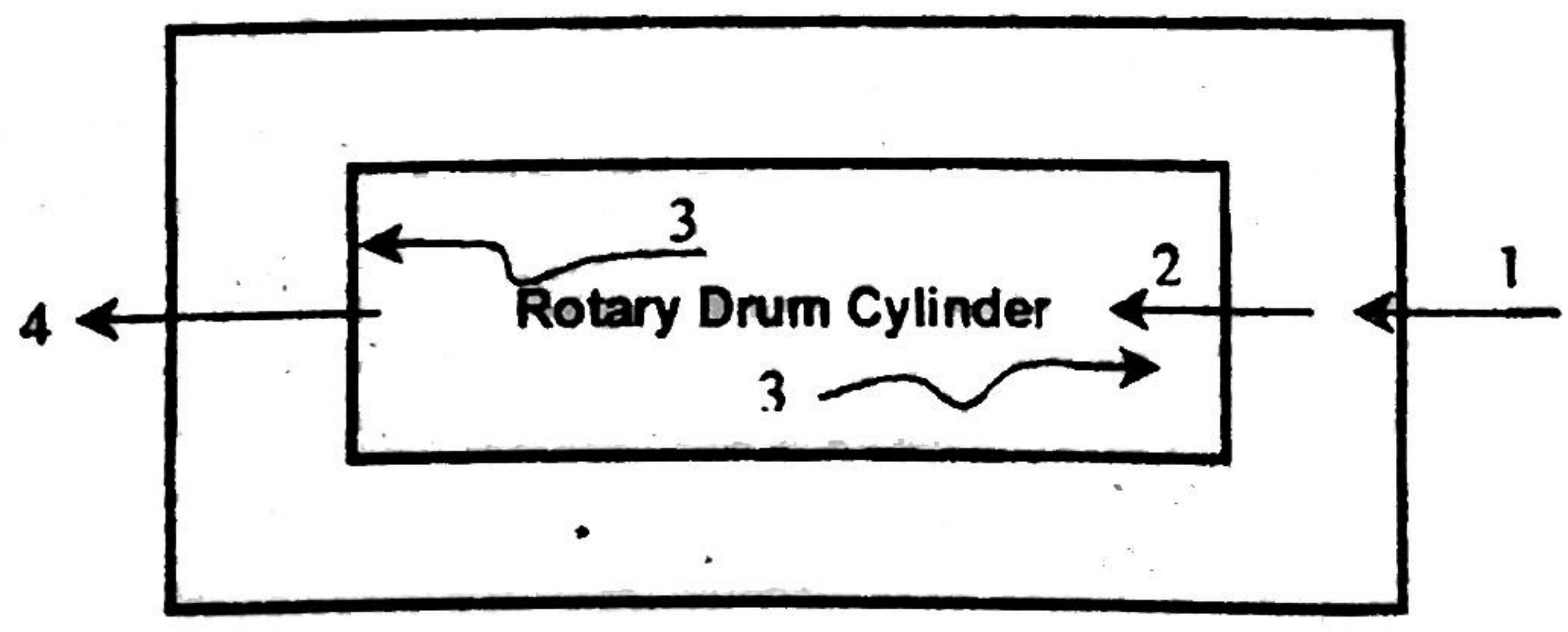

Figure 2. Schematic diagram of the rotary drum dryer 
A blower was also mounted to force the heated air to the cylinders starting at the inlet hopper going out to the outlet hopper on the same direction with the materials. The air was heated by 6 units of electric heating coils, which can produce six variable temperatures depending upon the number of heaters that are either turned on or off.

To vary the rotation of the drums, the dryer was also mounted with a variable speed motor, which is actually a system consisting of a 3-phase electric motor (Mindong Electric Co., Type Y90L-4, 2-kw) and an electronic RPM controller (TOSHIBA Industrial Inverter TOSVERT VF-nCl).

\section{Treatments}

The treatments were the combinations of the following factors: temperature $\left(75,94\right.$, and $\left.113^{\circ} \mathrm{C}\right)$, drum rotation $(15,20$ amd $25 \mathrm{RPM})$ and loading rate $(5,15$ and $25 \mathrm{~kg} / \mathrm{h})$. Three variables in each factor were evaluated making a total of 27 treatment combinations. Only a single flight design was used which had the following configuration: plain aluminum angle bars $(38 \times 38 \mathrm{~mm})$ with continuous length of the bar along the drum.

Using the Response Surface Methodology (RSM), the 27 treatment combinations were reduced to 15 treatments, which are shown in Table 1 following the fractional factorial design.

\section{The drying experiments}

The drying experiments started after 30 minutes pre-heating time to stabilize drying conditions. In each experiment run, the following procedure was followed:

1. Moisture contents of the samples before and after loading to the dryer were determined. Three 10-gram samples for every run was taken using an electronic weighing balance (SARTORIOUS: BP1200), dried in an oven (WTB Binder Labortechnik:E/B28) at $105^{\circ} \mathrm{C}$ for at least five (5) hours or until bone-dry weight was attained (AOAC, 1980).

2. The relative humidity and temperature of the ambient and exhaust air during the drying period were measured using the Hygro Thermo-Anemometer (EXTECH INSTRUMENTS, Model 407412), and were recorded every 10 minutes. The temperatures of the different locations inside and outside the dryer were monitored by the digital thermo-recorder (Ondotori Thermo 
Tablc 1. The is treatments derived by applying the fractional factorial design

\begin{tabular}{lccc}
\hline Treatment & $\begin{array}{c}\text { Loading Rate } \\
\mathrm{kgh}\end{array}$ & $\begin{array}{c}\text { Temperature } \\
\text { C }\end{array}$ & $\begin{array}{c}\text { Drum Rotations } \\
\text { RPM }\end{array}$ \\
\hline 1 & 5 & 75 & 15 \\
2 & 5 & 113 & 15 \\
3 & 5 & 113 & 25 \\
4 & 5 & 75 & 25 \\
5 & 25 & 75 & 15 \\
6 & 25 & 75 & 15 \\
7 & 25 & 113 & 25 \\
8 & 25 & 113 & 25 \\
9 & 15 & 75 & 15 \\
10 & 15 & 94 & 20 \\
11 & 15 & 75 & 25 \\
12 & 15 & 94 & 20 \\
13 & 5 & 94 & 20 \\
14 & 25 & 94 & 20 \\
15 & 15 & 94 & 20 \\
\hline
\end{tabular}

Recorder, Model TR-71S) and by the thermocouple probe (NOMADICS TC6 CardAcq) using a laptop computer (IBM Thinkpad).

3. The airflow of the drying air was measured using the Hygro ThermoAnemometer (EXTECH INSTRUMENTS, Model 407412) by placing the anemometer probe across the pipe where the blower forced the drying air.

4. The rotation in RPM of the rotary cylinder was measured using the tachometer. The RPM of drum rotation depends on the adjustment made on the variable speed electric motor.

5. To determine the effects of the different treatment combinations, the moisture content of the samples after passing through the dryer was determined, as well as its capacity and rate of moisture removal. Samples of cassava grates were loaded to the hopper and after 10 minutes of drying, grates flowing out of the dryer was collected for 3 minutes. After another 7 minutes, sample of grates flowing out of the dryer was again collected for 3 minutes. The same procedure was followed until the third time. The moisture content as well as the weight of each of the samples gathered in each particular time was determined. The moisture content determined at that particular time of measurement was considered the instantaneous moisture content and was used to compute for the rate of moisture removal. 


\section{Data gathered}

The following data were gathered for analysis which include initial moisture content, final mositure content, plain loss of water, rate of the plain loss of water, relative humidity of the exhaust and ambient air, temperature of the different parts of the dryer, and ambient air temperature.

The initial and final moisture contents of the sample were calculated on a percent dry basis using:

$$
M_{C}=\frac{W_{1} W_{f}}{W_{f}}
$$

where: $\mathrm{M}_{\mathrm{C}}=$ moisture content, dry weight basis, $\%$

$\mathrm{W}_{\mathrm{i}}=$ initial weight of the smaple before oven drying, $\mathrm{g}$

$\mathrm{W}_{\mathrm{f}}=$ final weight of the sample after oven drying, $\mathrm{g}$

The Rate of Moisture Removal (RMR) is the amount of moisture removed by the dryer at a particular given condition in a particular period of time. This was computed using the equation:

$$
\mathrm{RMR}=\mathrm{Wm} / \mathrm{t}
$$

where: $\mathrm{RMR}=$ rate of moisture removal, $(\mathrm{kg} / \mathrm{h})$

$\mathrm{W}_{\mathrm{m}}=$ weight ofmoisture removed, $(\mathrm{kg})$

$\mathrm{t}=$ time duration of getting each sample, $(\mathrm{h})$

\section{Statistical analysis}

Data gathered were subjected to statistical analysis. The rate of moisture removal of the grates was used to compare the different treatment combinations and determine the optimum combination that gives the maximum drying rate of the grates. Data were analyzed using the Response Surface Methodology that was similar to the procedure followed by Amestoso (1999): 1) Input of the data to the Excel Software according to the arrangement of increasing order of a defined variable specifically temperature for surface response regression 
analysis; 2) Incorporation of data to the Statistical Analysis Software (SAS) to get the significance of the ten (10) terms of the Central Composite Design (CCD) model and the critical points which determined the levels of the independent variables that defined the optimum combination of the drying operation and their study. The critical points where used to generate surface plots usng STATISTICA software. Conclusions were made according to the results of the modeling and the surface plots behavior.

\section{RESULTS AND DISCUSSION}

\section{Pre-evaluation test}

Preliminary tests were conducted to check whether there were some aspects of the dryer needing attention, to get acquainted with the different parts of the dryer that eventually facilitates data gathering routines, to establish the exact amount of materials needed for each treatment evaluation, and determine the amount of materials needed to be loaded to the hopper for each loading rate.

During the preliminary tests, temperature sensors were mounted to the different parts of the dryer that monitored and recorded the temperature reading continuously every experimental run. The three temperaure settings of $75^{\circ} \mathrm{C}$, $94^{\circ} \mathrm{C}$, and $113^{\circ} \mathrm{C}$ of the dryer were determined during these preliminary tests, as well as the preheating period of 30 minutes for the dryer to attain stability.

\section{Thermodynamic properties}

The schematic diagram of the thermodynamic condition of the dryer is shown in Figure 3. Point 1 shows the ambient air entering the heater. Point 2 is the state of air inside the drying chamber/cylinder. Point 3 is the state of exhaust air coming from the product inside the drums.

The results of the mean relative humidity of the ambient and exhaust air as well as the mean ambient air temperature are shown in Table 2. The mean ambient temperature varied from $24.62^{\circ} \mathrm{C}$ to $27.27^{\circ} \mathrm{C}$ while the relative humidity of the ambient and exhaust air varied from $75.09 \%$ to $81.9 \%$ and from $97.03 \%$ to $100 \%$, respectively. 
Table 2. Summary of the inlet and outlet average temperatures of the dryer

\begin{tabular}{llcc}
\hline Treatment & \multicolumn{2}{c}{ Temperatures. ${ }^{\circ} \mathrm{C}$} & $\begin{array}{c}\text { Average } \\
\text { Inlet }\end{array}$ \\
\hline Outlet & Temperature, ${ }^{\circ} \mathrm{C}$ \\
\hline T1 & 74.98 & 48.43 & 61.71 \\
T1 & 74.14 & 43.04 & 58.59 \\
T12 & 75.59 & 43.97 & 59.78 \\
T8 & 75.37 & 47.67 & 61.52 \\
T5 & 73.73 & 50.70 & 62.21 \\
T13 & 92.97 & 51.69 & 72.33 \\
T11 & 92.91 & 47.80 & 70.63 \\
T15 & 92.43 & 48.03 & 70.23 \\
T14 & 92.23 & 52.37 & 72.30 \\
T9 & 92.43 & 48.03 & 70.23 \\
T2 & 112.97 & 60.80 & 86.89 \\
T3 & 112.99 & 63.21 & 88.10 \\
T6 & 112.61 & 53.47 & 83.04 \\
T7 & 112.69 & 47.87 & 80.28 \\
T10 & 112.63 & 48.14 & 80.38 \\
\hline
\end{tabular}

As expected, the temperature on the inlet from the heater leading to the inner drum was higher than the exhaust portion of the outer drums in all the temperature settings. The decrease in temperature reading from the inlet chamber to the exit chamber was due to the transfer of available sensible heat of the dyring air to the drying chamber and also to the product, which had a temperature of less than $25^{\circ} \mathrm{C}$.

\section{Moisture removal of cassava grates}

The moisture removal of cassava grates was analyzed in terms of plain water loss and the rate of plain water loss as affected by temperature, loading rate and drum rotation.

\section{Plain water loss}

Results of statistical analyses of the data Tables $3 a$ and $3 b$, show that plain water loss was influenced by linear and quadratic terms of loading rate. This indicates that of all the factors under consideration the water removal was significantly affected only by the loading rate. An increase or decrease in loading rate corresponds to a relative change of value in plain water loss. 
Table 3a. ANOVA for plain loss of water of cassava grates

\begin{tabular}{lllll}
\hline Regression & $\begin{array}{l}\text { Degrees of } \\
\text { Freedom }\end{array}$ & $\begin{array}{l}\text { Type I Sum of } \\
\text { Squares }\end{array}$ & R-Square & F-Ratio \\
\hline Linear & 3 & 69.140735 & 0.5466 & $36.876^{* * *}$ \\
Quadratic & 3 & 7.257547 & 0.0574 & $3.871^{*}$ \\
Crossproduct & 3 & 0.106150 & 0.0008 & $0.0566 \mathrm{~ns}$ \\
Total Regress & 9 & 76.504432 & 0.6048 & 13.601 \\
\hline
\end{tabular}

ns - not significant

* significant at $\mathrm{P}<.05$

*** - significant at $\mathrm{P}<.001$

Coef. of Variance -33.2336
Response Mean - 2.378778

Root MSE - 0.790555

R-Square -0.6048

Table 3b. Parameter estimates for response surface of plain water loss of cassava grates

\begin{tabular}{lllll}
\hline Parameter & $\begin{array}{l}\text { Degrees of } \\
\text { Freedom }\end{array}$ & $\begin{array}{l}\text { Parameter } \\
\text { Estimate }\end{array}$ & $\begin{array}{l}\text { Standard } \\
\text { Error }\end{array}$ & $\begin{array}{l}\text { T for HO: } \\
\text { Parameter } 0\end{array}$ \\
\hline INTERCEPT & 1 & 8.728619 & 4.819492 & $1.81 \mathrm{~ns}$ \\
TEMP & 1 & 0.166930 & 0.108042 & $1.545 \mathrm{~ns}$ \\
LOADING & 1 & -0.307885 & 0.094974 & $-3.242^{* *}$ \\
RPM & 1 & -0.035263 & 0.343564 & $-0.103 \mathrm{~ns}$ \\
TEMP*TEMP & 1 & -0.000762 & 0.000558 & $-1.366 \mathrm{~ns}$ \\
LOADING*TEMP & 1 & 0.000173 & 0.000601 & $0.288 \mathrm{~ns}$ \\
LOADING*LOADING & 1 & 0.006450 & 0.002013 & $3.205^{* *}$ \\
RPM*TEMP & 1 & -0.000346 & 0.001201 & $-0.288 \mathrm{~ns}$ \\
RPM*LOADING & 1 & -0.000133 & 0.002282 & $-0.0584 \mathrm{~ns}$ \\
RPM*RPM & 1 & 0.001567 & 0.008051 & $0.195 \mathrm{~ns}$ \\
\hline
\end{tabular}

ns - not significant

** - significant at $P<0.01$

RPM - revolutions per minute
LOADING - loading rate

TEMP = temperature 
Water loss $=4.263-0.225^{*} x+0.062 * y+0.005^{*} x * x-0.001 * x * y-0.001 * y^{*} y$

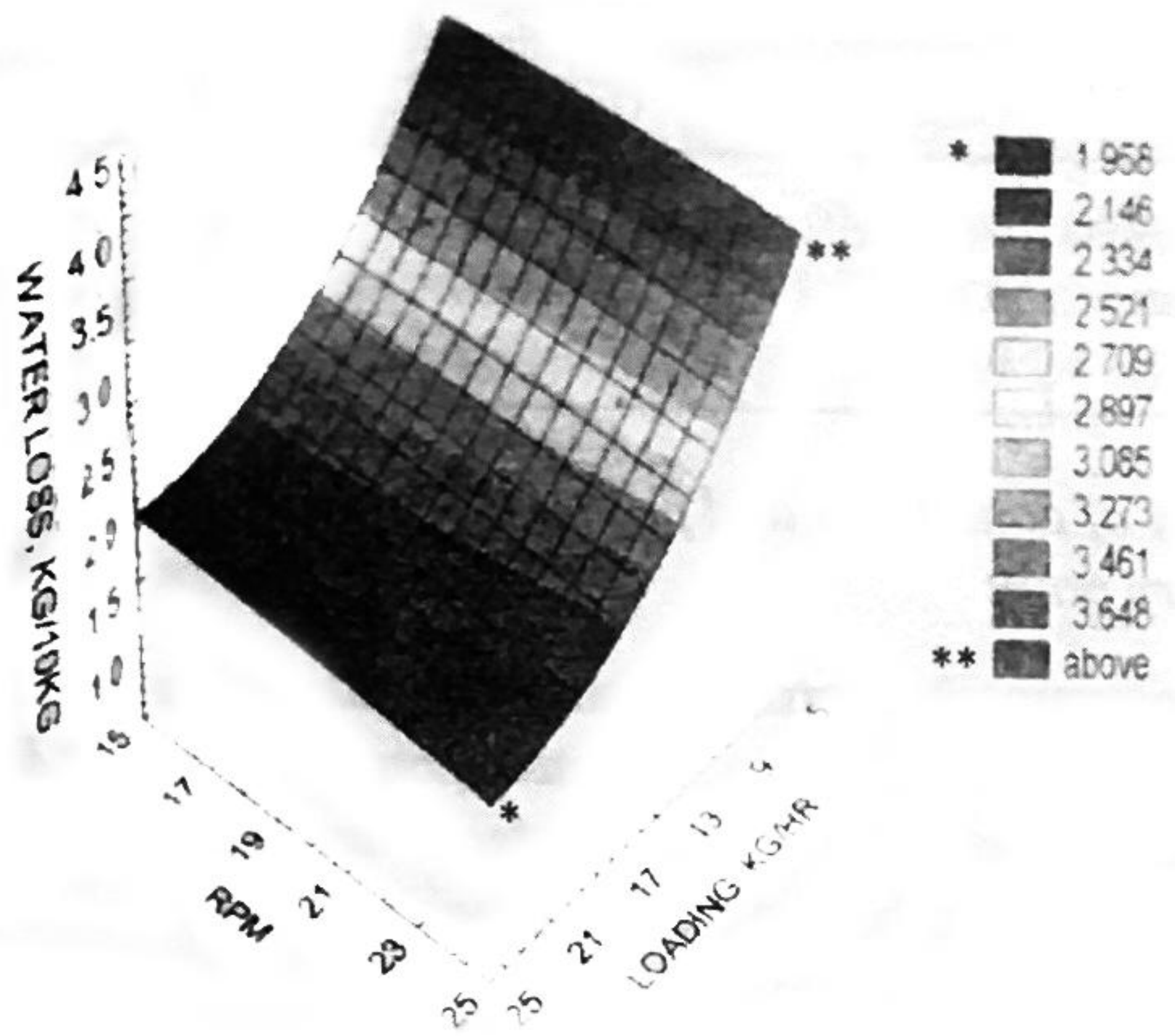

Figure 3. Surface plot for water loss $(\mathrm{kg} / 10 \mathrm{~kg})$ at constant temperature of $113^{\circ} \mathrm{C}$

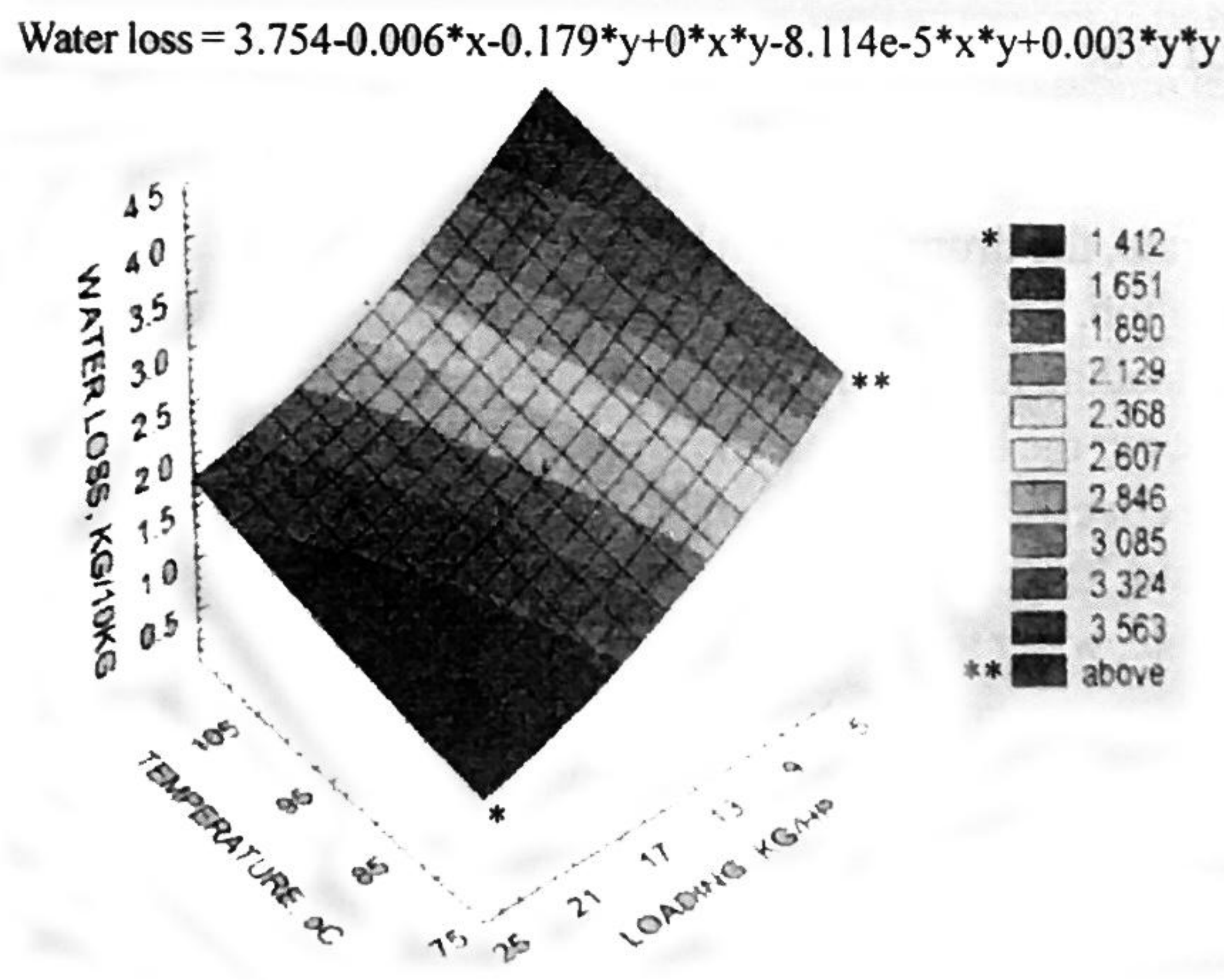

Figure 4. Surface plot for water loss $(\mathrm{kg} / 10 \mathrm{~kg})$ at constant RPM of 25 
Table 4. Optimum condition and predicted response value of plain water loss of cassava grates at stationary point

\begin{tabular}{|c|c|c|c|}
\hline \multirow[t]{2}{*}{ Factors } & \multicolumn{2}{|c|}{ Optimum Condition Critical Values } & \multirow{2}{*}{$\begin{array}{l}\text { Predicted Values at } \\
\text { Stationary Point }\end{array}$} \\
\hline & Coded & Uncoded & \\
\hline Temperature & $0.6675 \%$ & 106.684320 & \multirow{3}{*}{1.827483} \\
\hline Loading rate & 0.768254 & 22.682538 & \\
\hline RPM & 0.803362 & 24.016812 & \\
\hline
\end{tabular}

Summary of conditions and predicted values of plain water at stationary point

The summary of conditions and predicted response values for plain water loss of cassava grates at the stationary point is shown in Table 4. From the canonical analysis of response surface, the stationary point is a saddle point, which means that the conditions within the level of experiments could either be maximum to one variable but minimum to the rest within the region of experiment. The results indicated that the predicted repsonse conditions of plain water loss within the region of experiment that gives the higher waste removal is a drying condition in which there is $107^{\circ} \mathrm{C}$ temperature. $23 \mathrm{~kg} / \mathrm{h}$ loading rate and $24 \mathrm{RPM}$ drum rotation. The water removal values were observed to be inside the experimental values.

Figure 3 shows the effect of loading rate and drum rotation at constant temperature $\left(113^{\circ} \mathrm{C}\right)$ on the plain water loss of cassava grates. At a given loading rate, the drum rotation has no effect on the water loss. At a given drum rotation, water loss displays a saddle response where it decreases with increase loading rate down to a minimum and then increases. This indicates that the lesser the loading rate the greater is the water removal.

The effect of temperature and loading rate at constant rotation (25 RPM) on the water loss cassava grates samples is illustrated in Figure 4. At a given loading rate, water loss increases with an increase in temperature. At a given temperature, water loss shows a saddle response where it decreases with increased loading rate down to a minimum and then increases. It was observed that the effect between temperature and loading rate in the plain loss of water was opposite. This means that the lesser the loading rate the greater was the the variable speed electric motor. 
Figure 5 shows the effect of drum rotation and temperatures at constant loading rate $(25 \mathrm{~kg} / \mathrm{h})$ on the water loss. At a given temperature, drum rotation has no effect on the water loss. At a given drum rotation, water loss increases with an increase in temperature. This indicates that the greater the temperature, the greater was the loss of water from the samples of cassava grates.

The conditions predicted for water loss of $1.83 \mathrm{~kg}$ of the product at stationary point are: $106.7^{\circ} \mathrm{C}, 22.7 \mathrm{~kg} / \mathrm{h}$ loading rate and $24 \mathrm{RPM}$ drum rotation.

\section{Rate of plain water loss}

As shown in Tables $5 \mathrm{a}$ and $5 \mathrm{~b}$, the rate of plain water loss was influenced linearly by the lumped effect of temperature, loading rate and drum rotation. This means the rate of water removal was significantly affected by the combined individual effects of temperature, loading rate and drum rotation.

Summary of conditions and predicted values of rate of plain moisture loss at stationary point

Table 6 shows the summary of the predicted critical values of optimum conditions for the rate of plain moisture loss as well as the optimum critical values for each independent varibale. The common point where the three independent variables converged as estimated by the response surface regression is the stationary point.

The critical values of the drum rotation were observed to be about 26 $\mathrm{RPM}$ drum rotation, $23 \mathrm{~kg} / \mathrm{h}$ loading rate and $108^{\circ} \mathrm{C}$ temperature. The predicted values at stationary point converged around 0.13 , which is observed to be outside the experimental values. According to Baja (2003) this could be due to Central Composite Designs (CCD) ability to determine extreme effects.

Figure 6 shows the effect of loading rate and drum rotation at constant temperature $\left(113^{\circ} \mathrm{C}\right)$ on the rate of plain moisture loss of cassava grates. At a given loading rate, drum rotation has no significant effect on the rate of moisture removal. At a given drum rotation, the rate of moisture removal increases with decrease inloading rate. This indicates that the lesser the loading rate, the greater is the removed moisture per unit time.

The effect of temperature and loading rate at constant drum rotation $(25$ 
Table Sa ANOVA for rate of plain moisture loss of cassava grates

\begin{tabular}{lllll}
\hline Regression & $\begin{array}{l}\text { Degrees of } \\
\text { Freedom }\end{array}$ & $\begin{array}{l}\text { Type I Sum of } \\
\text { Squares }\end{array}$ & R-Square & F-Ratio \\
\hline Lincar & 3 & 0.100353 & 0.1967 & $2.932^{*}$ \\
Quadratic & 3 & 0.010078 & 0.0197 & $0.294 \mathrm{~ns}$ \\
Cross product & 3 & 0.000550 & 0.0011 & $0.016 \mathrm{~ns}$ \\
Total regress & 9 & 0.001981 & 0.2175 & $1.081 \mathrm{~ns}$ \\
\hline ns- not significant & Root MSE 0.106815 & \\
$\begin{array}{l}\text { - significant at P<.01 } \\
\text { Response mean }\end{array}$ & 0.155556 & R-Square 0.2175 & \\
\end{tabular}

Table Sb. Parameter estimates for response surface of rate of plain moisture loss of cassava grates

\begin{tabular}{|c|c|c|c|c|}
\hline Parameter & $\begin{array}{l}\text { Degrees of } \\
\text { Freedom }\end{array}$ & $\begin{array}{l}\text { Parameter } \\
\text { Estimate }\end{array}$ & $\begin{array}{l}\text { Standard } \\
\text { Error }\end{array}$ & $\begin{array}{l}\mathrm{T} \text { for } \mathrm{HO}: \\
\text { Parameter }=0\end{array}$ \\
\hline INTERCEPT & 1 & 0.447626 & 0.920908 & $0.48 \mathrm{~ns}$ \\
\hline \multirow{2}{*}{ LOADING } & 1 & 0.009263 & 0.020645 & $0.466]$ \\
\hline & 1 & -0.016861 & 0.018148 & $-0.929]^{*}$ \\
\hline RPM & 1 & -0.001940 & 0.065648 & $-0.0295]$ \\
\hline TEMP*TEMP & 1 & -0.000044629 & 0.000107 & $-0.419 \mathrm{~ns}$ \\
\hline \multicolumn{2}{|c|}{ LOADING TEMP $\quad I$} & 0.000021930 & 0.000115 & $0.191 \mathrm{~ns}$ \\
\hline \multicolumn{2}{|c|}{ LOADING*LOADING I } & 0.000339 & 0.000385 & $0.881 \mathrm{~ns}$ \\
\hline \multicolumn{2}{|c|}{ RPM*TEMP $\quad$ I } & -0.000017544 & 0.000230 & $-0.0764 \mathrm{~ns}$ \\
\hline \multicolumn{2}{|l|}{ RPM*LOADING } & -0.000033333 & 0.000436 & $-0.0764 n s$ \\
\hline \multicolumn{2}{|l|}{ RPM*RPM } & 0.000088889 & 0.001538 & $0.0578 \mathrm{~ns}$ \\
\hline \multicolumn{2}{|c|}{$\begin{array}{l}\text { ns - not significant } \\
\text { ] - lumped significant effect } \\
\text { TEMP - temperature }\end{array}$} & \multicolumn{3}{|c|}{$\begin{array}{l}\text { RPM - revolutions per minute } \\
\text { LOADING - loading rate }\end{array}$} \\
\hline \multirow[t]{2}{*}{ Factors } & \multicolumn{2}{|c|}{ Optimum Condition Critical Value } & \multirow{2}{*}{\multicolumn{2}{|c|}{$\begin{array}{l}\text { Predicted Values at } \\
\text { Stationary Point }\end{array}$}} \\
\hline & Coded & $\frac{\text { on Critical Value }}{\text { Uncoded }}$ & & \\
\hline Temperature & 0.752194 & 108.291685 & \multirow{3}{*}{\multicolumn{2}{|c|}{0.129056}} \\
\hline Loading rate & 07.64465 & 22.644655 & & \\
\hline RPM & 1.168747 & 25.843736 & & \\
\hline
\end{tabular}

Stationary point is a saddle point 
Water loss $=5.371-0.002^{*} x+0.635^{*} y+0^{*} x^{*} x-0.001^{*} x^{*} y-0.014^{*} y$

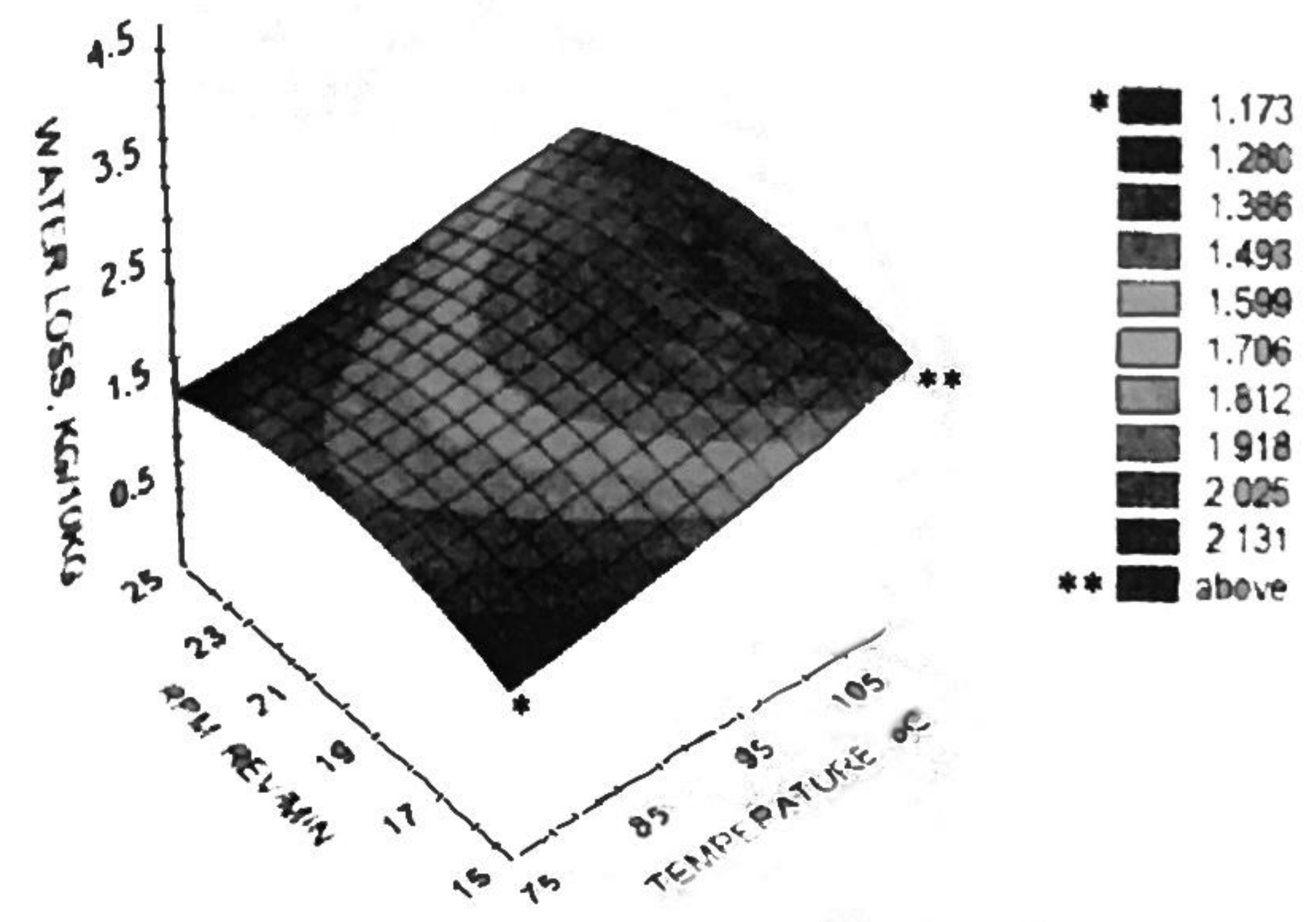

Figure 5. Surface plot for water loss $(\mathrm{kg} / 10 \mathrm{~kg})$ at constant lading of $25 \mathrm{~kg} / \mathrm{h}$

Rate of moisture loss $=0.012-0.001 * x+0.001 * y+1.747 e-5 * x^{*} x-5.051 e-6^{*} x^{*} y-1.298 e$

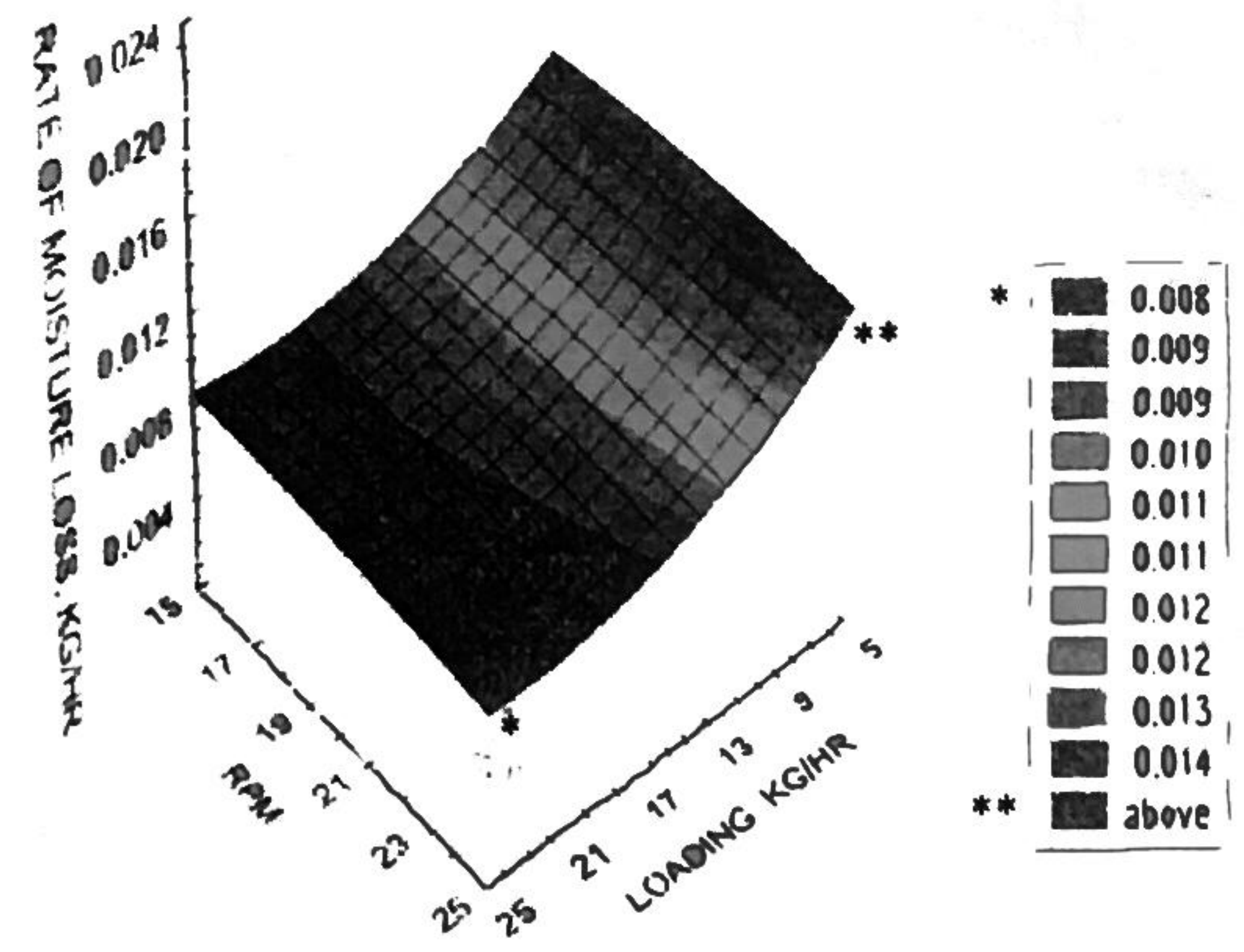

Figure 6 Surface plot for rate of moisture loss at constant temperature of $113^{\circ} \mathrm{C}$ 
Rate of moisture loss $=0.013-1.738 e-5^{*} x-0.001^{*} y+3.844 e-7^{*} x^{*} x+3.637 e-7^{*} x^{*} y+7.31$

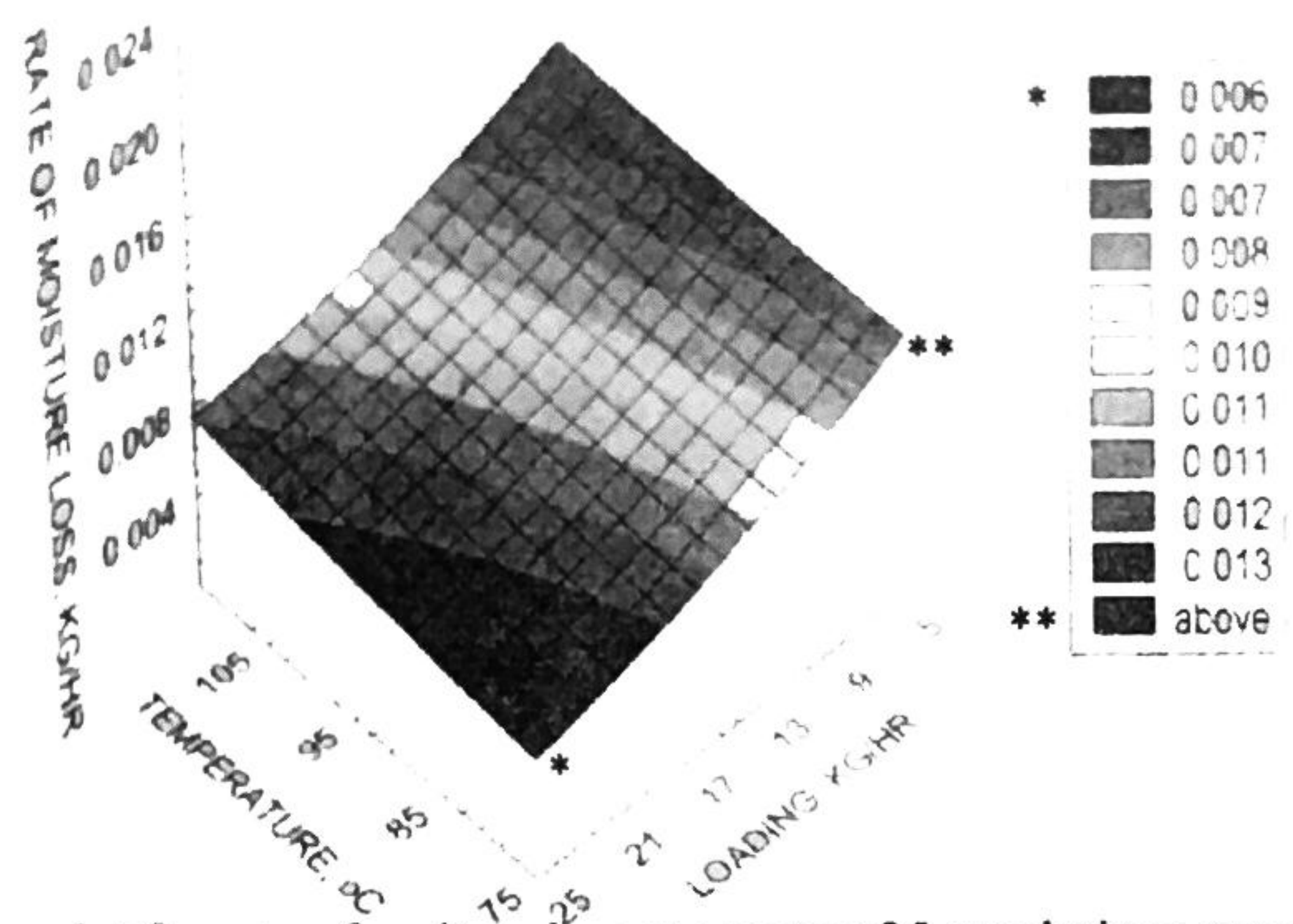

Figure 7. Surface plot for rate of moiture loss at constant 25 revolutions per minute

Rate of moisture loss $=0.023+3.813 e-5 * x+0.003 * y+6.425 e-7 * x * x-3.797 e-6 * x * y-5.6$

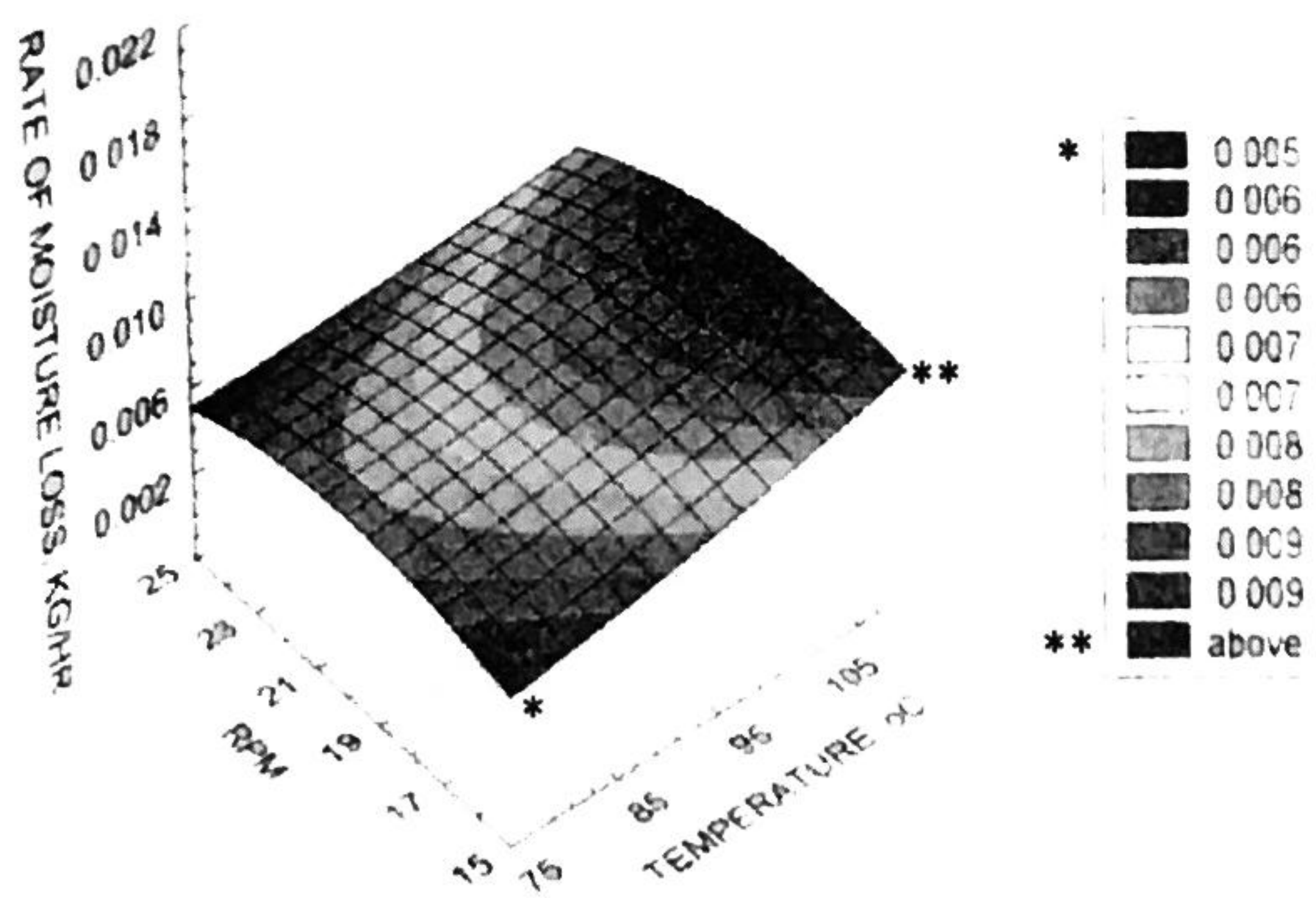

Figure 8. Surface plot for rate of moisture lossat constant loading rate of $25 \mathrm{~kg} / \mathrm{h}$ 
RPM) on the rate of plain moisture loss of cassava grates samples is illustrated in Figure 7. At a given loading rate, the rate of moisture removal increases with an increase in temperature. At a given temperature, the rate of moisture removal increases with a decrease in loading rate. The combined effect between temperature and loading rate that affect significantly on the rate of water loss is observed to be opposite. This means that an increase in the rate of moisture removal corresponds from a decrease and increase of loading rate and temperature, repsectively.

Figure 8 shows the effect of RPM and temperature at constant loading rate $(25 \mathrm{~kg} / \mathrm{h})$ on the rate of plain moisture loss of cassava grates. At a given temperature, drum rotation has no significant effect on the rate of moisture removal. At a given drum rotation, the rate of moisture removal increases with an increase in temperaure. It indicate that an increase of values in a temperature scale corresponds to an increase in the rate of moisture removal.

\section{CONCLUSION}

From the experiment conducted, response surface analysis revealed that the optimum combinations of the drying rate of cassava grates using the rotary drum dryer based on the plain water loss is $106.7^{\circ} \mathrm{C}$ temperature, $22.7 \mathrm{~kg} / \mathrm{h}$ loading rate and $24 \mathrm{RPM}$ of drum rotation.

\section{RECOMMENDATION}

Further studies may be conducted to include other factors in the optimization process such as diameter of the exhaust, diameter of the drum. angle of the flights, and airflow.

\section{ACKNOWLEDGEMENT}

The authors would like to acknowledge the International Foundation for Science (IFS) for funding the study. 


\section{I.IIT:RATURE CITED}

AMI STOSO. F. J. 1999. Single screw extrusion of pasta from sweetpotato (Ipomoea hatatas L ) flour. PhD Dissertation. UPLB Los Baños. Laguna Philippines.

A.O.A.C.1980. Official Methods of Analysis of the Association of Official Analytical chemists. 13th Edition. W. Horwitz (ed) Washington DC, USA

BAJA. A. J. 2003. Effect of frying time and temperature and thickness on the qualities of sweetpotato (Ipomoea batatas L.) chips. Undergraduate Thesis. Leyte State University. Baybay, Leyte.

COCK.J. H. and E. J. WEBER. 1978. Casscrva harvesting and processing. Proceedings of a workshop hld at CIAT, Cali,Colombia.

Philippine Council for Agriculture, Forestry and Natural Resources Research and Development (PCARRD). 1983. The Philippine Recommends for Cassava. Philippine Council for Agricultural Resources and Development. Los Baños, Laguna.

TAN, D. L. S., K. MIYAMOTO, K. ISHIBASHI, K. MATSUDA and T. SATOW. 2000. Process and product analysis of the village scale processing of sweetpotato in the Philippines. J. Japanese Soc. Agri. Machinery. 62(4):160-174.

TAN, D. L. S., K. MIYAMOTO, K. ISHIBASHI, K. MATSUDA and T. SATOW. 2001. Thin-layer drying of sweetpotato chips and pressed grates. Trans. ASAE 44(3):669674.

TAN, D. L. S., and K.A. B. CODILLA. 2003. Performance evaluation of the IFSPhilRootcrops Laboratory Dryer. Undergarduate Thesis. Leyte State University, Baybay, Leyte.

TAN, D. L. S., R. R. ORIAS, R. V PIEDRAVERDE. 2004. Technical Improvement of the Rootcrop Grates Processing System. (DA-BAR-funded Project). Terminal Report, PhilRootcrops. Visca, Baybay, Leyte.

TROUNG VAN DEN. 1987. State of the Art: Processing and utilization of cassava and sweetpotato for food. Paper presented to the symposium on the state of the art in Rootcrop Technologies. Philippine Rootcrop Research and Training Center, Visca. Baybay, Leyte. 